\title{
Penetrating the City
}

\author{
Cyndra MacDowell
}

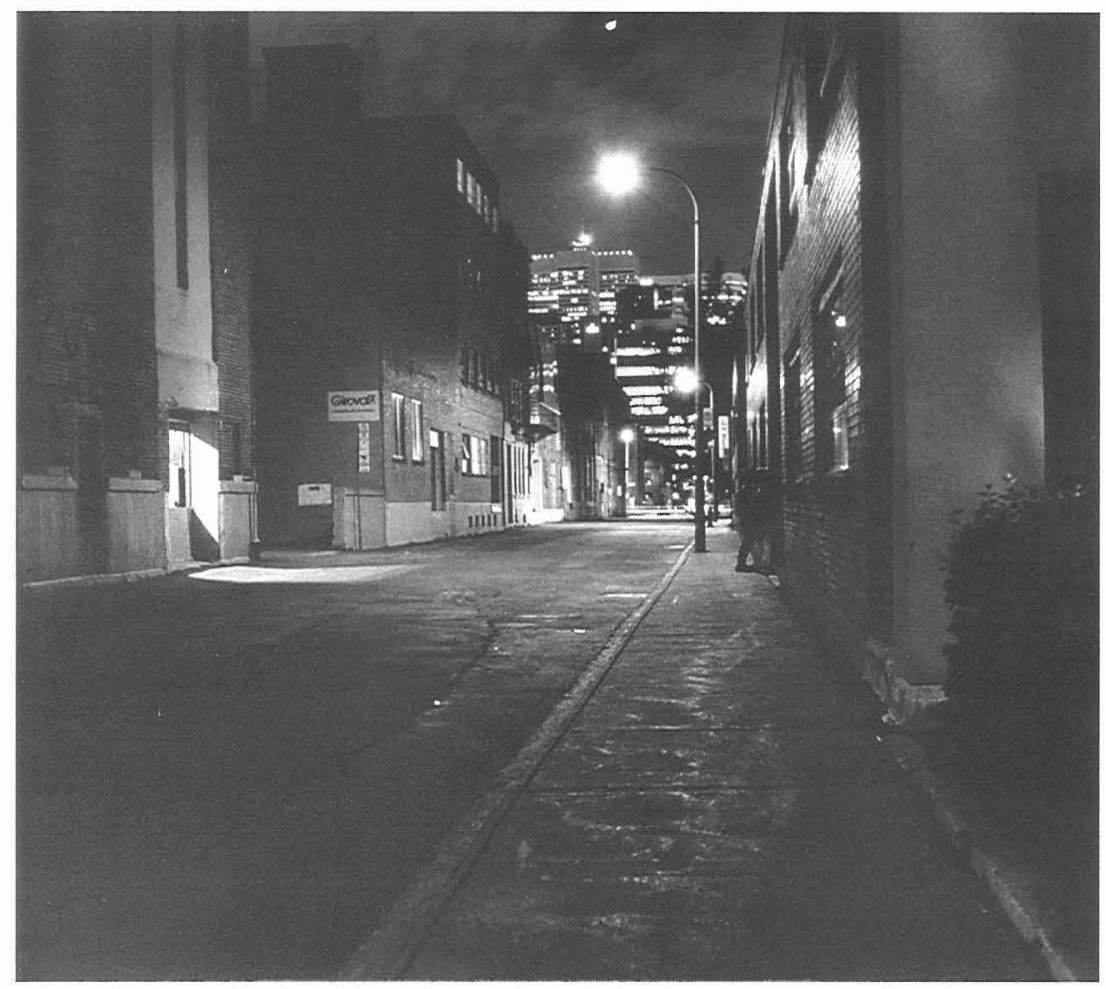

Untitled (Street, Old Montl.), 1999, gelatin silver print, $30^{\prime \prime} \times 30^{\prime \prime}$ 


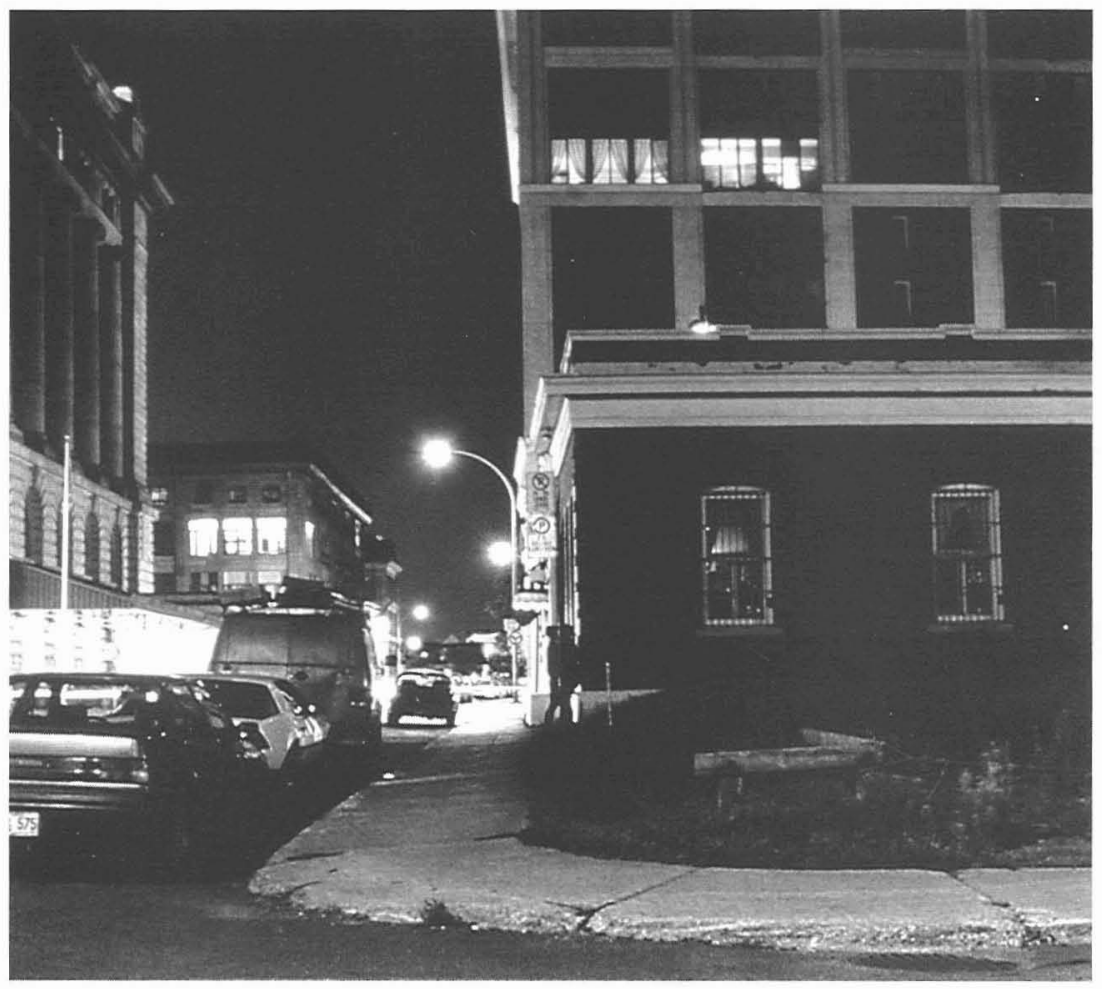

Untitled (Resto., Old Montl.), 1999, gelatin silver print, $30^{\prime \prime} \times 30^{\prime \prime}$ 